\title{
The 2010 euro crisis stand-off between France and Germany: leadership styles and political culture
}

\author{
Frank Bohn • Eelke de Jong
}

Published online: 8 March 2011

(C) The Author(s) 2011. This article is published with open access at Springerlink.com

\begin{abstract}
In this paper, we argue that the severity of the 2010 euro crisis was caused by and reveals differences in leadership styles and political culture between European countries, especially between France and Germany. We trace these differences to differences in underlying values: culture. There is a historic pattern, visible especially during the European integration process. Cultural differences explain differences in attitude towards leadership and IMF involvement, lead to a stand-off and, thereby, dramatically increase the uncertainty about the commitment of the eurozone and the EU towards Greece.
\end{abstract}

Keywords Euro · Debt crisis · Greece · Culture · France and Germany · IMF

JEL classification $\mathrm{F} 34 \cdot \mathrm{Z} 13$

From November 2009 to June 2010, the Euro lost $20 \%$ of its value. The crisis seemed to culminate prior to the European Union (EU) summit on 6 May 2010 with both the value of the euro plummeting and stock prices tumbling world-wide, but it was in June when the Euro reached its lowest value in 4 years with 1.20 \$ per Euro. The Euro crisis began, arguably, with the admission by Greek Prime Minister, Georgios Papandreou, shortly after his election in October 2009, that "our economy is in intensive care". The expression of concern by European finance ministers at the end of November preceded the downgrading by ratings agencies of Greek's long-term debt to BBB + and, ultimately (by Standard and Poor on 27 April), to $\mathrm{BB}+$, a rating for junk bonds.

F. Bohn $(\bowtie) \cdot$ E. de Jong

Department of Economics, Radboud University Nijmegen, P. O. Box 9108, 6500 HK Nijmegen, The Netherlands

e-mail: f.bohn@fm.ru.nl

F. Bohn

Department of Economics, University of Maryland, 3105 Tydings Hall, College Park, MD 20742, USA 
Eventually, Greece overhauled its public finances and received all the aid it needed to avoid default at least for the next couple of years. But why did it take so long? Many accused German Chancellor Angela Merkel of having dragged out the inevitable decisions. These "pundits" blame her for the magnified financial fall-out in terms of the size of the required aid package as well as the contagion effects to other EU member countries like Ireland, Portugal, Spain, and, possibly, even the United Kingdom (UK). Other "pundits" argue that the delays were necessary to have the Greek public, not just the government, acknowledge the need for drastic measures domestically before allowing them access to external aid. Merkel also wanted to involve the International Monetary Fund (IMF) as a stringent monitor, less prone to political pressures than European institutions may be. This was faced by strong opposition by French Prime Minister Nicolas Sarkozy who would have preferred to keep the IMF out of the picture because he views it as a US-dominated institution despite the fact that a Frenchman is the managing director of the IMF. The different approaches lead to a stand-off between Sarkozy and Merkel which was only resolved at the EU summit on 6 May 2010.

In this article, we argue that the Euro crisis stand-off reveals differences in leadership styles and political culture between European countries running deeper than a superficial study of events would suggest. Moreover, we claim that the severity of the Euro crisis can be explained by those differences in leadership styles and political culture. We would like to distinguish three connected aspects. First, there are differences in the underlying perception of the role of the government and the relationship between the market and the government. These differences give us a first indication of the diversity in solutions for the crisis preferred by major European countries. Second, there are differences in leadership styles which affect the interaction between key European decision makers, and which, too, are rooted in cultural differences. Third, underlying attitudes towards rules and power determined many of the points of view put forward in different countries, in particular Germany and France, during the entire process of European monetary integration as well as during the recent Euro crisis. Again, we can trace them back to cultural differences.

\section{The role of government versus the market}

It is no secret that the perception of the role of the government versus the market varies across (European) countries. The Anglo-Saxon view (UK, but also the US) represents one extreme of the spectrum. Markets have a dominant role, the government only provides the regulatory framework. Large firms have a dispersed ownership. Hostile take-overs are viewed as an appropriate measure for correcting mismanagement. Under normal circumstances, governments do not own companies and the size of the government is relatively small.

The other extreme of the spectrum is the Latin view held by France and most Southern European countries. The government plays a large role in the economy including public ownership of companies. The government's involvement is quite dirigistic and in some periods private companies have been nationalized, for instance French banks in the beginning of the 1980s. Top managers frequently move from state companies to the public sector and vice versa. Private firms have a concentrated ownership. The dominant owner can be the government or a family (Portugal). 
Hostile takeovers are not regarded as a good instrument for correcting management. Since the dominant owners are members of the (supervisory) board, they can correct management directly. Both society at large and organizations have a hierarchical structure. Often there is a hostile attitude towards market-type solutions. France is particularly hostile when an Anglo-Saxon involvement is suspected, for instance whenever the IMF is to intervene.

The German Soziale Marktwirtschaft (social market economy) could be placed in between. The role of government is not as central as in the Latin model; it has to provide the rules for the well-functioning of markets, but companies could well be owned by (state) governments. Many firms belong to the Mittelstand, the category of medium sized companies. Until the beginning of the 21 st century banks were quite often dominant owners of listed companies. In these cases, they often provided the chairperson of the supervising board and were able to influence management both through credit lines and through their supervisory role. This might explain the German reluctance with respect to hostile takeovers. Their attitude towards markets is less hostile than the French, however. The term social market economy already suggests a market economy with smoother features than the Anglo-Saxon version.

The distinction of perceptions of the government versus the market is substantiated by research kicked off by Hofstede (1980). ${ }^{1}$ In the original study four factors (dimensions as he calls them) are found to explain differences in national cultures: Power Distance, Individualism, Masculinity and Uncertainty Avoidance. The first and the last factor largely explain the differences in perception of the government versus the market. Power Distance (PD) refers to the extent to which a society accepts that power, within its organisations and the society as a whole, is distributed unequally. Such countries typically have hierarchical structures in politics, society and economics. A high PD score reflects the belief that "inequality is a normal and desirable thing" (rather than something to be avoided). Uncertainty Avoidance (UA) captures how much a society is worried about something unknown. A high UA score reflects a sense of fear (rather than curiosity) when confronted with uncertainty.

France scores high on both Power Distance and Uncertainty Avoidance, whereas Germany has a relatively low score on Power Distance and scores in the medium range on Uncertainty Avoidance. High scores of Power Distance and Uncertainty Avoidance correspond to a critical attitude towards markets ${ }^{2}$ and, thus, explain the habitual dislike of markets in France and the restrained scepticism in Germany. These scores also epitomize country-specific attitudes towards the government. ${ }^{3}$ France's high score on PD indicates that in France power prevails over right; whoever holds the power is right and good, and the powerful should have privileges. There is less dialogue and more violence in domestic politics. France's high score on UA is compatible with the idea that citizens are incompetent when dealing with authorities, especially since the government is

\footnotetext{
${ }^{1}$ See De Jong (2009, Appendix I) for an overview of survey studies on cultural dimensions. The original (and key) study was Hofstede (1980) which covers 116,000 questionnaires of IBM employees in 40 countries. See also Hofstede et al. (2010).

${ }^{2}$ See De Jong (2009, Ch. 5) for an overview of studies on cross-country differences in institutions and culture.

${ }^{3}$ See Hofstede et al. (2010), Table 3.5 and Table 6.5.
} 
seen as an insurance against uncertainty. (Incidentally, this was taken to the extreme in Greece which also has a high score on UA: the welfare state was expanded to unsustainable proportions.) Hofstede et al. (2010, p. 340) summarize the culture profile of France as one where power prevails. German's low score on PD corresponds to the idea that the use of power must be legitimised by following moral criteria. Everybody should have equal rights and there is much dialogue in domestic politics. Its medium score on UA indicates that its citizens are regarded as more competent in their dealings with authorities than the French. Hofstede et al. (2010) summarize this as the dominance of order. This cultural configuration implies that Germany is more favourable for market type solutions than France, although not as much as the Anglo-Saxon world. Moreover, as we will see in the next section these cultural differences play a significant role in the manner the French and Germans have handled the Greek crisis.

\section{Leadership styles}

The different attitudes towards supporting Greece were represented by politicians with different personalities, especially German Chancellor Angela Merkel and French President Nicolas Sarkozy. The Economist (2009) describes Merkel's character "by what she is not. Unlike other European leaders, she is neither charismatic, nor flashily intellectual, nor domineering. Yet nobody could deny that she is a highly effective politician. ..., she is cautious by temperament. The opposite of France's Nicolas Sarkozy, she is more of a methodical scientist than a mercurian revolutionary." A year before, The Economist (2008) is baffled by Sarkozy's "thundering pace and reckless disregard for the rules. ... He repeatedly startled France's traditional ally, Germany, with unexpected proposals. He forged a hasty (and flawed) peace deal in Georgia without a formal mandate-sidelining the EU's foreign policy chief, Javier Solana. At the EU-Russia summit, he went far beyond his remit by criticising the notion of American missile defences in Poland and the Czech Republic." However, Merkel is not only startled by Sarkozy, but Sarkozy is also startled by Merkel according to Proisl (2010, p. 25): “"In dealing with Merkel the president is permanently under the impression [that he is] being deliberately misled', says an official who routinely sees both leaders interact."

Why are there such misunderstandings? Differences in character may determine their differences in how to approach politics, but the different political systems in Germany and France reinforce those differences. Sarkozy is typically seen as a man of action. We could debate whether he has a vision for what he is doing or it is merely activism, but he says that he likes "pushing his peers [EU leaders] towards 'less talk and much more action"” according to The Economist (2008). Merkel, in contrast, is not only "cautious by temperament" (The Economist 2009), some even accuse her of trying to sit out problems, but she is also vigorously opposed to putting forward a vision for the EU "'because I believe that defining long-term goals sometimes makes it more difficult to take the necessary next political steps" (Proisl 2010, p. 18). The French presidential system allows Sarkozy to push ahead with his political agenda, whereas the coalition government in Germany requires Merkel to take a much more guarded approach. She even had to face disagreement from her 
most senior cabinet member, finance minister Wolfgang Schäuble, who belongs to her own party (Proisl 2010, p. 25).

The differences in the political system are indeed reflected by how many voices represent Germany or France in the debate over how to help Greece. On the French side of the debate, Sarkozy was omnipresent. In Germany, many different views could be heard. For instance, a finance minister spokesman rejected the idea of a European fund on 15 February 2010. On 23 February, state of Berlin finance minister, Ulrich Nußbaum, said that Greece could expect support only, if it helped itself. Another few days later (on 1 March), former ECB chief economist Otmar Issing recommended Greece to turn to the IMF. "The lack of a central authority in the German political system and the resulting slowness and confusion are unimaginable in France's highly centralised presidential system." (Proisl 2010, p. 25.) In France, political hierarchy is accepted, whereas Germany has a federal and much more consensus-oriented system. As discussed in the previous section, this cultural difference between France and Germany is captured by the higher Hofstede (1980) scores for uncertainty avoidance (UA) and power distance (PD) in France. According to research done by Gulbro and Herbig (1998) "Cultures with high Power ratings will spend less time on compromising. ... Perhaps compromise is seen as a sign of weakness ... ." They report differences in the time share spent on persuasion and compromise during negotiations. For Germany, it is 30.1 and $27.5 \%$, respectively; for France, it is exactly $15 \%$ for each of the two activities.

\section{Power and rules}

Given the aforementioned differences in leadership styles and in the perception of role of the government versus the market it is not surprising that France and Germany could barely avoid a stand-off over how to support Greece. However, so far we have only dealt with basic attitudes. In this section, we would like to show that cultural differences also produced some tangible policy differences in the past. Our examples link different aspects and episodes of European monetary integration to France's and Germany's conduct during the recent Euro crisis.

The first example refers to the first years of the European Monetary System (EMS) and illustrates the differences between France and Germany in attitude towards the role of the market. The first years of the EMS witnessed many occasions in which the French franc had to be devalued against the other currencies, in particular the Deutsche mark and the Dutch guilder. Time and again France accused the latter countries of a lack of solidarity. According to the French the defence of a currency should be symmetric in that both the monetary authorities of the weak and the strong currency should intervene in the foreign exchange market. That was also the reason why the European Currency Unit (ECU) was introduced as a divergence indicator: the currency the farthest away from the parity should be obliged to take action, be it the strong or the weak currency. Germany, however "was not willing to jeopardize its own stability by coming into rescue of weaker currencies" (Bakker 1994, p. 196). Germany and The Netherlands became tired of being put into the defensive and having to reject proposals to finance deficits without notable adjustments in the deficit countries. As a reaction The Netherlands suggested to 
reintroduce capital liberalization; a long-forgotten objective of the European Community. It hoped that such a mechanism would enhance discipline among the weaker member states. "Germany was attracted by the idea that liberalization would strengthen market forces and thus would put pressure on governments to follow stability-oriented policies" (Bakker 1994, p.200). In March 1983, François Mitterrand gave in and followed a more stability-oriented policy.

This example shows many similarities with the developments during the first months of 2010. Once again France asked for solidarity in the sense of the strong countries financially helping the weak, in particular Greece. As outlined in Section 1, power should prevail. Germany once again argued that the Greeks had to put their own house in order first and plead for an external force (the IMF in this case) which would discipline the weak country.

The following examples illustrate the difficulties French politicians, coming from a high PD country, have with accepting an authority they cannot control. This can be illustrated by the early discussions on the independence of a European central bank, the unwilling acceptance of the first President of the European Central Bank (ECB), and the automatic sanctions mechanism of the Stability and Growth Pact (SGP). The cultural differences between Germany and France on the independence of the ECB go back to the failed negotiation on the 1970 plan for a European Monetary Union, the Werner report. During the negotiations, the German Minister of Economic and Financial Affairs, Karl Schiller - backed by the Bundesbank - voiced the hope that a future ECB would be as politically independent as the Bundesbank. In contrast, French President Pompidou stressed the need for politicians to have political control over the monetary instruments. The level of democratic control over and political independence of the future ECB remained contentious until the end of the Wernernegotiations, and, ultimately, contributed to their failure (Van Esch 2007, pp. 205209 and 215). The issue of political influence on the board of the ECB popped up again in 1998 when the first President of the ECB had to be appointed. Whereas all other heads of state agreed with Wim Duisenberg, the French President, Jacques Chirac, opposed him. He even wanted to split his term in office of 8 years into two terms of 4 years, which would have enabled Chirac to promote his candidate Trichet after 4 years. In the end, Duisenberg agreed to sign that he would not serve the entire term of 8 years. Chirac had asserted himself during the meeting: "Je ne me laisse pas faire chanter par un petit fonctionnaire" (De Haas and Van Lotringen 2003, p. 25). This quote nicely illustrates the difficulties French politicians, their Presidents in particular, have with accepting the power of non-elected leaders.

French politicians also dislike to be restricted by automatic rules. Germans on the other hand prefer strict rules. This cultural difference came, amongst others, to the fore when both France and Germany breached the Stability and Growth Pact's budget deficit limit of $3 \%$ of GDP in 2001. The German government reckoned with the possibility that it would have to pay fines. In the ECOFIN-meeting it "promised to monitor national and Land government budget figures and spending on social benefits more closely ... and to respect its commitment to a balanced budget by 2004" (Howarth and Loedel 2004, p. 843). France, on the other hand, resisted compliance with the budget rules, arguing that it could undermine economic recovery and therefore make it even harder to manage deficits in the future (see Howarth and Loedel 2003, p. 171). In the end, both governments resisted adhering to the requirements of the Commission. However, the 
German government was heavily criticised by the Bundesbank, German industry, and the majority of the population, whereas in France no protest of any significance was raised. When automatic sanctions were again discussed after the recent crisis, the French Minister of Finance, Christine Lagarde accurately summarized the French position during a meeting on the taskforce chaired by Van Rompuy on 18 October 2010. In her view the rules to be agreed upon refer to economic governance, and the word governance originates from the Latin word 'governare' which means to rule. To rule is politics. Hence the beginning and the end of economic governance has to be political and thus automatic sanctions cannot be implemented; according to her they disregard the essential role to be played by politicians.

During the recent crisis the French President (as well as others) would not even want to accept the authority of the existing Maastricht Treaty in several respects. First, Sarkozy did not have any problems with promising financial support to Greece without a mandate and despite the no-bail-out rule stipulated by the Treaty. Agence France Presse reports on 7 March 2010: "European governments sharing the euro currency will help Greece out of financial crisis 'if necessary', French President Nicolas Sarkozy said Sunday after talks with the Greek prime minister." There was no serious debate on this issue in the French public. In contrast, both German politicians and the media were agonizing over a possible violation of the no-bail-out clause. Second and in a similar vein, there was fierce opposition in Germany when the ECB announced that it would buy up Greek bonds. Bundesbank President Weber publicly made his objections known. Spiegel Online even titled: "German Central Bankers Suspect French Intrigue” (Reuter, 2010). Third and contributing to the impression of a conspiracy, Sarkozy had demanded from the ECB to do just that, i.e. buy up Greek bonds. This by itself is already an infringement on the independence statute of the ECB.

\section{Conclusion}

In this article we have described the different attitudes prevailing in Germany and France with respect to the relative role of the government versus the markets, the leadership styles, and the role of politicians and politics in economic affairs. We have traced these differences to differences in underlying values: culture. We have shown that there is a historic pattern and that these cultural differences have hampered European monetary integration in the past. More importantly, however, we claim that these cultural differences still play a role and explain the way European leaders handled the Greek crisis in 2010. The incompatible differences in appreciation of market forces and Anglo-Saxon solutions in Germany versus France hampered a quick agreement on the best way to solve the crisis. In particular, the possible involvement of the IMF was at stake at this stage. This indecisiveness was reinforced by the fact that no single authoritative speaker emerged on the German side. In the international press, Merkel was even pictured as someone who is lacking leadership. Such a criticism would be disastrous for a French president, who, by nature, is expected to be on top of it all.

As a result of these cultural differences in major European countries, the uncertainty about the attitude of the eurozone and the EU towards Greece increased dramatically. Financial markets became nervous and demanded ever higher returns 
on Greek bonds. In the end what started as doubts about the credibility of one member state's government and the sustainability of its debts, ended as a crisis of the entire euro area, even though the country concerned forms only a small part of the euro area's GDP. We therefore conclude that the severity of the Euro crisis was caused by and reveals differences in leadership styles and political culture.

Open Access This article is distributed under the terms of the Creative Commons Attribution Noncommercial License which permits any noncommercial use, distribution, and reproduction in any medium, provided the original author(s) and source are credited.

\section{References}

Agence France Presse, 7 March 2010

Bakker AFP (1994) The liberalization of capital movements in Europe: the monetary committee and financial integration 1958-1994, PhD dissertation. University of Amsterdam

De Haas B, Van Lotringen C (2003) Wim Duisenberg: Van Friese volksjongen tot Mr. Euro. Uitgeverij Business Contact, Amsterdam

De Jong E (2009) Culture and economics: on values, economics and international business. Routlegde, London

Gulbro RD, Herbig P (1998) Cultural differences in international negotiating. Int J Value Based Manage 11:265-273

Hofstede G (1980) Culture's consequences: international differences in work-related values. Sage, Beverly Hills

Hofstede G, Hofstede GJ, Minkov M (2010) Cultures and organizations: software of the mind, intercultural cooperation and its importance for survival. McGraw Hill, New York

Howarth DJ, Loedel PH (2003) The European central bank: the new European Leviathan? Palgrave, Basingstoke

Howarth DJ, Loedel PH (2004) The ECB and the stability pact: policeman and judge? J Eur Public Policy 11(5):832-853

Proisl W (2010) Why Germany fell out of love with Europe, Brussels: bruegel essay and lecture series

Reuter W (2010) ECB buying up greek bonds - German central bankers suspect French intrigue, Spiegel online, 31 May 2010

The Economist (2008) The magnificence of Nicolas Sarkozy. 389(8611):80

The Economist (2009) The mystery of Mrs Merkel. 392(8637): 14

Van Esch FAWJ (2007) Mapping the road to Maastricht: a comparative study of German and French pivotal decision makers' preferences concerning the establishment of European Monetary Union during the early 1970s and late 1980s, unpublished PhD dissertation Radboud University Nijmegen 